\title{
Concrete Prehistories: The Making of Megalithic Modernism
}

\begin{abstract}
After water, concrete is the most consumed substance on earth. Every year enough cement is produced to manufacture around six billion cubic metres of concrete ${ }^{1}$. This paper investigates how concrete has been built into the construction of modern prehistories. We present an archaeology of concrete in the prehistoric landscapes of Stonehenge and Avebury, where concrete is a major component of megalithic sites restored between 1901 and 1964. We explore how concreting changed between 1901 and the Second World War, and the implications of this for constructions of prehistory. We discuss the role of concrete in debates surrounding restoration, analyze the semiotics of concrete equivalents for the megaliths, and investigate the significance of concreting to interpretations of prehistoric building. A technology that mixes ancient and modern, concrete helped build the modern archaeological imagination.
\end{abstract}

Concrete is the substance of the modern -"Talking about concrete means talking about modernity" (Forty 2012:14). It is the material most closely associated with the origins and development of modern architecture, but in the modern era, concrete has also been widely deployed in the preservation and display of heritage. In fact its ubiquity means that concrete can justifiably claim to be the single most dominant substance of heritage conservation practice between 1900 and 1945. This paper investigates how concrete has been built into the construction of modern pasts, and in particular, modern prehistories. As the pre-eminent marker of modernity, concrete was used to separate ancient from modern, but efforts to preserve and display prehistoric megaliths saw concrete and megaliths become entangled. What has been described as the 'untimeliness' of concrete (see below) was essential to the formation of modern conceptions of the Neolithic.

Our archaeology of concrete examines two of England's most famous prehistoric landscapes Stonehenge and Avebury. The total number of known prehistoric sites listed within the Stonehenge and Avebury World Heritage Site numbers in the thousands, although many are no longer visible as landscape features. We focus on locations where concrete is crucial to the display of megaliths as prehistoric visitor attractions, including the Neolithic henges of Stonehenge and Avebury, along with the lesser known Woodhenge, Sanctuary and Devil's Den. Our research builds on existing studies which have documented the contribution of a range of twentieth century activities to the production of the heritage landscapes of today (Edwards 2000, Barber 2014a, 2014b). We concentrate on the period between 1901 - when the first concrete was poured at Stonehenge - and 1939, when war and depleted finances brought an end to Alexander Keiller's concreting at Avebury. Megalithic concreting would reach its apogee in the 1950s and 60s with the concrete megastructure of the West Kennet Long Barrow (Piggott

1 From Cohen, Jean Louis and Moeller, Martin (eds.) (2006) Liquid Stone: New Architecture in Concrete (Princeton Architectural Press) 
1962) and the public spectacle of megalithic concreting at Stonehenge between 1958 and 1964 (Cleal et al 1995). The post-war era of 'new brutalist' concrete megaliths deserves a programme of research in its own right. The current paper considers the formative phase of megalithic concreting when architects and archaeologists formulated policies and practices allowing heritage concrete to spread throughout the later twentieth century.

We begin with a brief introduction to concrete, before discussing how heritage concrete was understood before and after the First World War. Situating concrete in relation to debates surrounding historical restoration, we suggest war and the development of modernist architectural styles transformed the meanings of heritage concrete. Concrete both separated ancient from modern and mixed them together. Fragments of sarsen megalith and other site components were used as aggregate, literally mixing modern and prehistoric elements. Next, we investigate the designs of concrete markers indicating the locations of vanished megaliths at Woodhenge, Avebury and the Sanctuary, analysing how concrete markers signify the prehistoric and the modern simultaneously. The next section - 'Concretizing Labour' examines the work of architects and building firms at Neolithic megaliths, suggesting concreting was part of a politics of building practices connecting modern labour to interpretations of prehistoric building. In conclusion we reflect on the ruination of the British modernist Neolithic and the futures of heritage concrete.

\section{$<1>$ A Concrete Introduction}

Concrete is made up of cement, sand, aggregate, and water. Mixing these together in the correct proportions (usually 1 part cement, 2 parts sand to 4 parts aggregate) produces a liquid that sets rock-hard at room temperature. The crucial component is cement. When mixed with water, this amalgam of clay and calcareous material (usually limestone or chalk) seeps into the voids between the other components, binding them together as it dries.

Concrete is an ancient material. The dome of the Pantheon is one of many Roman-period structures - including some viaducts and roads - made from concrete (Stanley 1979: 3-6). However, concrete owes its world domination to modern industrialization. The beginnings of the present phase of concrete's history are often set around Joseph Aspdin's patenting of Portland Cement in 1824 (Collins 1959, 36, Stanley 1979,11). Towards the end of the nineteenth century, the invention of béton armé (reinforced concrete) took place more or less simultaneously in France, England and the United States (Collins 1959, Croft 2004). The invention of industrial concrete was spread between "chemists and engineers who invented cements, industrialists whose prime interest was in the commercial exploitation of cement production, and ordinary builders who by trial and error on the building site developed the practical application of the material, and subsequently the technique of reinforcing it with steel" (Forty 2012: 16). Because concrete developed through interactions among different collectivities, it has not maintained a single historical identity. Understandings of what concrete is and how it might be used differ from place to place; concrete's meanings have not remained stable over time. 
Concrete became the stuff of modernity's dreaming during the nineteenth century. Popular for imaginative follies, seaside amusements and new utopias, 'liquid stone' could be substituted wherever stone had been used traditionally - in buildings and roads, for example. But concrete was soon floated where stone had never been, in the form of 'ferro-cement' boats for instance (first floated in 1849; patented 1855). By the middle of the century, public parks and seaside promenades were ornamented with spectacular rockeries and waterfalls crafted in Pulhamite Rockwork, a proprietary cement designed to imitate the appearance of natural stone (English Heritage 2008). Benjamin Waterhouse Hawkins cast dinosaurs and other extinct species in concrete for the grounds of the Crystal Palace in 1852 (Secord 2004). In the hands of Thomas Edison, concrete became the all-purpose substance of utopian mass-produced futures. Edison cast entire houses complete with concrete fittings and furniture, including a concrete piano (Bergdoll \& Christensen 2008; Weary 2009). By beginning of the twentieth century, the Portland Cement Association's 'Everyday Uses of Cement' (1913) documented a bewildering variety of commonplace uses, from farm buildings and fences, to tables and tombstones.

Concrete was widely used in monumental and memorial architecture, although often hidden behind stone cladding. Memorial concrete became more visible after the First World War. America's first Great War memorial was a full-scale concrete reconstruction of Stonehenge at Maryhill, Washington. The concrete Stonehenge was designed by businessman and pacifist Sam Hill after he had visited the real Stonehenge with Lord Kitchener, Britain's Secretary of State for War. Both Hill and Kitchener believed Stonehenge was once a site of human sacrifice. Begun in 1918 , before the war was over, the Maryhill monument connected the deaths of American soldiers with the sacrificial victims of prehistory (Tuhy 1983).

While some found the boundless limits of concrete exhilarating, others detected the beginnings of destabilizing simulation. Concrete appeared to have no intrinsic form. This lead some architects and critics to consider it "unnatural" and "morally questionable" (Moeller 2006:156). Viollet le Duc had set out the history of architecture as a series of styles, each of which was held to express the inherent qualities of particular building materials (le Duc cited in Moeller 2006). But concrete adopted any form available - and to this extent, went against the laws of architectural periodization. John Ruskin had argued for "truth" in materials, insisting materials be used in ways expressing their logical inherent properties; no material should be made to look like another or to fulfil another's role (Ruskin 1871). Although Ruskin voiced this idea in opposition to 'Iron Gothic' (including the work of le Duc), the same principle could be extended to concrete. In an era when architecture was held to reveal the moral condition of society, concrete was morally dubious - all the more so when it came up against ancient buildings. Concrete restoration could be seen as "a lie" twice over. Restoration in any case was "a lie from beginning to end" (Ruskin 1871 [1849], 162). Furthermore, concrete's formlessness betrayed the idea that buildings should express the "truth" of materials. Finding an inherent form for concrete has been seen as the great problem of late nineteenth and early twentieth century architecture (Forty 2006). It was only from the 1920s - with the spread of architectural modernism - that the 'problem' of concrete was resolved. Modernist architectures claimed to finally express the inner "truth" of reinforced concrete. 
Concrete embodies time. The process of mixing concrete, then allowing it to set, requires duration and appears to freeze time. This was especially so in an era affording little attention to how concrete would age. The notion that concrete, unlike wood or stone, would never decay was a significant selling point in the early twentieth century. Many concrete promoters seemed oblivious to the idea that concrete could age. The Portland Cement Association repeatedly stressed that concrete was not only "clean and sanitary", "fire-resisting", "impervious to liquids" and "vermin-proof", it was also "not subject to decay". In preservation works, concrete was thought to arrest decay in other materials. Concrete 'Tree Dentists' attempted to prolong the life of ancient trees by replacing rotting wood with concrete inside still living tree trunks (Portland Cement Association 1913).

In fact, concrete did age - but it did not age in the same way as previous ruins. Concrete didn't acquire the patina and wear associated with Ruskin or Riegl's "age value" and beloved by 'antiscrape' conservationists. Albert Speer renounced steel and concrete because they would not produce the ruins that Hitler envisaged as memorialising the Third Reich in future millennia (Speer in Krier 1985:214). Concrete disturbed concepts of the romantic ruin established in the eighteenth and nineteenth centuries (Woodward 2001). It disrupted "received modes of historical temporality" (Yablon 2010:10). Presenting new forms of ageing, concrete disturbed received modes of ruination to the extent that it appeared partly outside established ways of ordering time - it became "untimely" (Yablon 2010:8-11).

"Discussion about concrete over the last century and a half [has] always stressed its newness. It was 'new' in the 1850s, and it is still, somewhat bizarrely, talked about as new today" (Forty 2006: 38, Croft 2004). The newness of concrete led some to speak of entering a new Concrete Age. "Antiquarian and scientific research", announced the Cement Marketing Company, "has amply demonstrated the wonderful changes" of the Stone Age, the Bronze Age, and the Iron Age; "we of to-day, however, are living in another epoch-making age [of] The Birth of Cement" (Advert in the Times, May 24 ${ }^{\text {th }} 1922$ ); "We have passed through what has been termed the steel age" announced the Portland Cement Association in 1913, "and are now in the concrete age" (Portland Cement Association 1913:4). Charles Peers (who as Chief Inspector of Ancient Monuments was responsible for concreting some of England's most important historic places) jokingly referred to the new "Concrete Age" he had inserted into many stratigraphical sequences (quoted in Thurley 2013: 4), and the uppermost stratigraphy of many heritage sites is indeed made of concrete. Peer's "Concrete Age" was a consequence of the fact that concrete already embodied periodicity. Concrete separated and purified 'new' from 'old' (Latour 1993). Concrete's ability to signify the modern was crucial to its deployment at heritage sites. Concrete signalled modern interventions, while, seen against the concrete, megaliths and earthworks were highlighted as historical features. Yet, as we will go onto to explain, purifying modern from prehistoric necessarily produced new entanglements between these periods.

$<1>$ From Cementing to Concreting Megaliths, 1901 - 1921 
In 1872, the preservation of ancient monuments became a matter of urgent debate. That year saw Lubbock's first attempt at legislating to protect prehistoric monuments from the ravages of time or indifferent owners. Megaliths - previously seen as romantic ruins naturally composed of leaning and prostrate monoliths - were now discussed as accidents waiting to happen, with stones that might topple at any minute (as indeed some did). The apparently precarious balancing of certain megaliths was no longer accepted as picturesque ruination. It became a problem requiring architectural solutions. Concrete was first advanced for Stonehenge in the early 1880s (Petrie 1880; Anon 1883; Pitt Rivers 1893). Stone 56 (in Flinders Petrie's numbering scheme) was the tallest stone still standing at Stonehenge, part of its colossal inner sarsen horseshoe. The massive monolith had been central to Turner and Constable's romantic paintings. Some now claimed Stone 56 was leaning at an alarming angle - although others considered it perfectly stable. The owner of Stonehenge - Sir Edmund Antrobus - was firmly anti-restoration. His few public utterances suggest a Ruskinian distrust of restoration, and a preference for letting buildings fall down rather than restoring them as "lies" (Hill 2008, 142; Barber 2014a). Antrobus' sole concession was to provide timber support for one trilithon, but only to ensure the safety of visitors, not to preserve the monument. Archaeologists were dismissive (e.g. Pitt Rivers 1893). Re-erecting Stone 56 would not be restoration, they insisted. The stone was leaning because of excavations in the seventeenth century. This was incorrect, but was nonetheless a powerful argument against those who saw Stonehenge as a 'natural' ruin. If Stone 56 was leaning because of human intervention, there was a "sacred" duty to resurrect it (Lukis 1881).

In 1900 a Stonehenge upright and lintel crashed to the ground, seemingly vindicating the archaeologists - though these were not stones they had identified as endangered. Stone 56 did not fall, but was selected for concreting. It was raised, the stone hole partially excavated, and then concreted upright using cement hidden under turf. Today, the monolith stands alone and erect, as it could only have done briefly, if at all, in prehistory, when it would have been stabilized by a lintel and partner stone. No one would again experience the romantic ruin portrayed by Turner and Constable (Noyes 1913). Instead, Stone 56 would draw the attention of modernists including Bill Brandt, Walter Gropius, Henry Moore, John Piper and Barbara Hepworth (Pitts 2008, Martin et al 1937). The concreting of Stone 56 represents the first stage in Stonehenge's modernization.

The work at Stonehenge was preventative, but soon led onto the re-erection of fallen megaliths. In December 1911 one of the Longstones at the western end of Avebury's Beckhampton Avenue toppled. 'Adam' was re-erected in concrete under the directorship of prominent Wiltshire archaeologist Maud Cunnington and her husband Benjamin. At the same time, the Cunningtons concreted a megalith in the West Kennet Avenue said to have fallen around 1889. Both stones were raised using jacks, wire ropes, timber shoring and wedges. The bases of their excavated stone holes were lowered a few inches, possibly to allow a deeper foundation. Then, once the stones were lowered into position, concrete was poured around to the level of the natural chalk and covered with soil and turf (Cunnington 1913). Later concreters claimed the West Kennet megalith was concreted into the wrong hole, while 'Adam' had been re-erected upside down (Keiller and Piggott 1936). 
After the First World War concrete architecture entered a new phase. Modernizers increasingly promoted "hygienic", "fire-proof" and "economical" concrete as the solution to needs for postwar "concrete cottages", roads and farm buildings (Lakeman 1918). While concrete was transforming the Western Front, there was a parallel militarization on Salisbury Plain. Firing ranges, practice trenches, bunkers, tank defences, gun emplacements, new roads and military buildings (including an aerodrome at Stonehenge) spread concrete across the landscape. From 1917, prehistoric sites were surrounded by geometrically shaped concrete markers intended to defend them from military encroachment or damage (Letter, Charles Peers to Sir Lionel Earle, 22 Jan 1918, The National Archives (TNA) WORK 14/214). Designed by the military, the size and abstract shapes of these markers foreshadow those archaeologists used to indicate missing megaliths in later decades (see below).

Re-erecting prehistoric megaliths in concrete was not especially controversial before the First World War. On the contrary, refusing to concrete suspect megaliths was often seen as unacceptable neglect. Attitudes to concrete before the First World War were markedly different to those of the 1920s and after. From the 1880s, as we have seen, preservationists including Petrie and Pitt-Rivers envisaged concrete as a substance which prolonged the life of fragile monuments by cementing historic fabric in position. The concreting of Stone 56 had the blessing of William Morris' Society for the Preservation of Ancient Buildings (SPAB). It was overseen by the architect Detmar Blow - a personal friend of both Ruskin and Morris. Blow's concreting plans were based on suggestions and sketches by Morris' close friend, the leading Arts \& Crafts architect and co-founder of SPAB, Philip Webb (letter from Webb, $16^{\text {th }}$ January 1901: SPAB Stonehenge file). In their previous restoration projects like that at St Mary's Church, East Knoyle, Webb and Blow used cement primarily for holding key structural elements in place (Dury 2000; SPAB St Mary's, East Knoyle file). Heritage concrete at megalithic sites seems to have been understood as a hard-setting adhesive holding historic elements in place. Relatively little attention seems to have been paid to the structural possibilities of concrete before the 1920s. Accordingly, there is no mention of iron or steel reinforcement before 1919 in the Stonehenge or Avebury landscapes. In keeping with its role as invisible 'glue', pre-war cement was usually disguised. The attention of viewers was supposed to focus on the ancient; the modern cement holding it in place was unimportant, and was generally concealed - either behind original fabric and facing materials (as at St Mary's Church) or beneath turf at Stonehenge and Avebury.

Under the influence of wider changes in architecture, archaeology and society the meanings of concrete changed after World War I. Warfare, industrialization and architectural modernism reinvented the ways that concrete mattered in the modern world. The spread of modernist architecture meant more and more people experienced buildings that did not disguise the fact they were made out of concrete. Associated with these changes, there was a shift in the meaning of concrete at the Stonehenge and Avebury megaliths. Before the First World War the substance securing stones in place was understood as 'cement'. After the war interventions came more and more to resemble structural additions, and concrete was not only unconcealed, 
but often prominently displayed; heritage concrete was coming into its own as a building material in its own right.

The beginnings of these shifts in concrete's meanings and uses can be seen at the Devil's Den dolmen near Avebury. There, for the first time, the concrete was reinforced (TNA WORK 14/665; Passmore 1922). The massive Devil's Den capstone and supporting stones - previously apprehended as picturesque - were now interpreted as precarious and in danger of collapse. The Office of Works devised a reinforced concrete buttress to secure them (see Figure 1). Concrete was cast in situ inside wooden formwork and the restorers then raised the surrounding ground level by around two feet to hide the concrete. Here concrete was more than an adhesive; the ferro-concrete buttress was an entirely new structural intervention.

Today, concrete is generally associated with creeping globalisation - the 'concrete jungle' that obliterates local distinctiveness. Before 1945 however, the concrete used at megaliths was largely a local material. Although Portland Cement was marketed and distributed as a commodity over long distances, concrete's other ingredients were typically sourced locally, with aggregate often quarried on site. At the Stonehenge and Avebury megaliths the concrete mix deliberately included materials derived from the prehistoric sites. Chalk could not be used as aggregate, since it interfered with cement chemistry, but that did not prevent the use of other locally sourced materials such as washed flint and other stones. Excavated fragments and chippings from megaliths, among other prehistoric materials and artefacts, were mixed into the concrete. At Devil's Den, for which the fullest set of Office of Works' instructions survive, it was specified that "sarsen stones lying near the monument can be incorporated in the foundations" (Office of Works Memo, 13/8/21: TNA WORK 14/665) along with broken flints from a nearby gravel pit. Megalithic concrete is far from being exclusively modern; it is not easily severable from the substance of the prehistoric.

In the 1920s and 1930s, concreting entered an uncomfortable phase of public scrutiny and recrimination. As reinforced concrete came into its own as an architectural material, it was increasingly difficult to maintain that concreting did not involve structural additions. At this point arguments made more than half a century earlier by Ruskin against Iron Gothic and restoration began to be applied to heritage concreting. Morris' SPAB, previously supportive of concreting megaliths, now argued concreting was deception, particularly where this modern support was hidden from view. Although Charles Peers maintained "It is better to risk a deception by inconspicuous additions than to proclaim them by conspicuous and unsympathetic materials" $(1931,320)$, critics of his policies were increasingly able to argue that using hidden concrete was 'faking' the past (see Thurley 2013).

A matter of weeks before the First World War ended, Stonehenge was gifted to the nation. The Office of Works, in conjunction with the Society of Antiquaries, immediately set in motion a programme of excavation and concreting. It was at this time that the newly controversial nature of concrete was revealed. Reinforced concrete was deployed within an ambitious building scheme intended to encompass much of the monument. However, the programme encountered unforeseen difficulties. For stones 6 and 7, the first to be tackled, Peers predicted 
each stonehole would contain clear evidence of precisely where each stone originally stood. That proved not to be the case (Barber 2014a). Moreover, straightening stones 30 and 1 meant that their neighbours (29 and 2) also had to be adjusted to ensure the connecting lintels refitted, irrespective of archaeological evidence for their original positioning. Work halted abruptly in late 1920, with no reasons given, but within the atmosphere of controversy now surrounding Office of Works' preservation policies. By the late 1930s, the Office of Works' response to requests to recommence concreting was that erecting stones without clear evidence of their original position could be construed as 'faking' Stonehenge (Office of Works Memo $8^{\text {th }}$ August 1938: TNA WORK 14/646). Megalithic concrete had changed from a cement merely securing stones, to "concrete" - a material used to make new, modern, buildings.

[Insert Figures 1 and 2 approximately here]

\section{$<1>$ Concrete Bollards and Untimely Obelisks, $1927-1939$}

Among the most remarkable elements of the Stonehenge World Heritage Site are the concentric rings of concrete cylinders at Woodhenge (Figure 3). Put in place in 1927, they embody the principles of Le Corbusier's Towards a New Architecture, which was first translated into English in the same year (Le Corbusier, 1927). Such "primary forms", are more beautiful, as Le Corbusier stated, because they are more clearly appreciated by the eye. An archaeological plan made concrete, Woodhenge follows Le Corbusier's rule that "the plan is the generator", and its concentric geometry manifests his principle of "regulating lines". There is little evidence that the excavators of Woodhenge - Maud and Benjamin Cunnington - knew anything about international modernism, nor that they ever read Le Corbusier. Yet, their concrete settings at Woodhenge, and later at The Sanctuary, are undeniably modernist.

[Insert Figure 3 approximately here]

Between 1927 and 1939 decisive shifts in concrete visibility occurred. Since 1901 concreting had been a public spectacle, attracting onlookers and contemporary press coverage, including newsreel footage. Once laid, however, Office of Works policy insisted concrete be hidden. Concrete was not mentioned in official guidebooks. At Stonehenge, where archaeological excavations necessitated by restorations were acknowledged, and findings described, the concreting was not. From the late 1920s however, concrete became a visible presence at megaliths. Archaeologists needed to permanently display traces of vanished megaliths encountered through excavation; however, restoration was increasingly controversial. Whatever was used to display the monument, it must not be faked ${ }^{2}$. At Woodhenge, the

${ }^{2}$ Restoration was not only a problem for the Cunningtons. Somewhat hypocritically - given his own use of concrete in the restoration of Roman sites - Mortimer Wheeler objected strongly to Keiller's reconstruction of Avebury: "I am perfectly prepared to believe that in another fifty years what Keiller and I propose to be right will be regarded as outrageously wrong... I therefore feel very doubtful about the proposed reconstruction of stones in what, in the light of present- 
"problem" was that of marking the locations of vanished uprights, while avoiding "anything that could be construed as an attempt to reconstruct the monument" (Cunnington 1929, 2). Concrete supplied a marker of modernity that declared 'newness' in its very substance. Made fully visible, even conspicuous, it could not be seen as a 'lie'. To stop at concrete's 'newness', however, is to deny its other fascinating temporalities. Concrete megalith signifiers operate in more than one temporal register. The concrete cylinders, rectangles, squares, discs and obelisks that appeared at Woodhenge, the Sanctuary and Avebury from the 1920s are untimely signifying both modern and prehistoric simultaneously.

Woodhenge comprises a new era in the megalithic Concrete Age - the first attempt to use concrete, not in support of existing elements, but to indicate the trace of an absence. Concrete is an inherently indexical medium, since it relies for its shape on moulds and is therefore always the trace of an absence (Forty 2012: 217). Archaeological uses of concrete double this effect since the size and shape of the moulds are related to "moulds" discovered in the ground in the form of excavated stone and post holes. Concrete megalith markers are indexes physically connected to prehistoric features (Peirce 1998:5). At Woodhenge pre-cast concrete drainpipes filled with concrete rubble and capped with cement were positioned over the centre of each excavated hole. Each was sized to index the dimensions of uprights in the six concentric posthole rings, their concrete caps painted in different colours for each ring. At the centre the excavated burial of a prehistoric child - thought, at the time, to be a sacrificial victim - was memorialized using a concrete bed set with large natural flint nodules, its shape recalling the mounded earth of a freshly filled grave.

The prehistoric monuments created by the Cunningtons in the 1920s and 1930s were essentially archaeological drawings made concrete. The Cunningtons repeatedly stressed the functionality of their concrete as an index of the site plan. The Woodhenge drainpipes were simply "the best way that could be thought of... preserving and showing the plan" (Cunnington $1929,2) ;$ "The drain pipes filled with concrete were not beautiful, but ... the plan could be seen" (ibid. , our emphasis) and it was this drive to construct an index of an index that stimulated further elaboration in concreting. In 1930, the Cunningtons excavated the lost stone circle at The Sanctuary, Avebury (Cunnington 1931). To produce equivalents for the megaliths more closely resembling archaeological site plans they crafted bespoke formwork and cast their concrete on site. Light blue rectangles stood for standing stones; dark red cylinders symbolized wooden posts. As at Woodhenge, a colour-coded brass plaque mounted on a concrete pedestal provided a key to what was essentially a map rendered in 3D concrete form.

Visitors to Stonehenge once believed it was made of a special sort of concrete, harder, even, than stone (Barber 2014a). Concrete is stone-like, and in this sense concrete megalith

day science, may be regarded as the correct fashion, but in a manner which must ultimately produce a twentieth-century sham" (letter, Wheeler to Office of Works, $22^{\text {nd }}$ February 1937: TNA WORK 14/1508). 
substitutes imitate megaliths. The "iconic" properties of concrete in relation to sarsen (see Peirce 1998: 5) were especially important at Avebury, where concrete had to respond, not just to plans and excavated holes, but also to re-erected megaliths. Unlike the "harassing appearance of Mrs Cunnington's solid drainpipes" (letter, Keiller to W Ormsby-Gore, $3^{\text {rd }}$ December 1936: Alexander Keiller Museum), Alexander Keiller's concrete "stelae" were specially designed as fitting complements to the megaliths. Keiller's stelae were produced on site by the Avebury "Concreting Gang", with Keiller himself among the party turning out the first casts (ibid). The stelae had to be "longer than they were broad, being of adequate length to show the direction of the Avenue (as if the stone had actually stood where each was placed)", they had to be "tall enough to give an impression of the line of the Avenue to anyone standing some distance away", while also not looking "unsightly" (ibid). Keiller experimented with concrete mixtures to enhance the affinities between his concrete and sarsen. His second stelae design ("Model 2") "used a different type of cement, and also of grit, which [gave] a very pleasing unobtrusive shade of grey to the finished surface" (Letter, Keiller to J Raby $23^{\text {rd }}$ July 1937: Alexander Keiller Museum).

The majority of the Avebury stelae were of models 1 and 2; designed in the shape of Egyptian obelisks (Figure 3). The installation of 61 obelisks at Avebury was informed by Keiller's awareness of Egyptian archaeology and knowledge of occult traditions surrounding the obelisk in Europe (Curran et al 2009). Keiller collected Egyptian Ushabti figurines and amassed an important library of esoteric and occult literature (now part of the National Library of Scotland). He owned eighteenth century manuscripts written by William Stukeley, who had been among the first to write of "obelisks" at Avebury. Keiller installed a massive concrete monolith called "The Obelisk" exactly where Stukeley had identified a prehistoric "obelisk" in the 1740s (Piggott 1950:117-8, 126). Both Keiller and Stukeley lived through periods in which Egypt was en vogue; Stukeley through the revival of interest surrounding eighteenth century antiquarianism and freemasonry (see Haycock 2002:131), and Keiller through the early twentieth century revival associated with the discovery of Tutankhamen's tomb. As designer and architect, Keiller was especially fond of the Art Deco Egyptianizing style. His unbuilt designs for a Stonehenge museum couple Egyptian elements - pyramidally angled walls - with aspects of Wessex prehistory - massive trilithon-like lintels (Murray 1999). The popularization of Grafton Elliot Smith and W. J. Perry's hyperdiffusionist theories by the journalist H.C. Massingham (e.g. Massingham 1926), lent further weight to associations between Avebury and Egypt. Stonehenge, Avebury and Silbury Hill, Massingham contended, were built by Egyptian immigrants. Although Keiller and his collaborator, Stuart Piggott, disassociated themselves from Massingham's hyperdiffusionism, Piggott nonetheless explored co-authoring a book with him (Stout 2008: 171). The notion of some connection between prehistoric Wessex and the ancient East was widespread in the interwar period (Renfrew 1973). The Avebury stelae signify the ancient obelisk, the traditions of Western antiquarianism and occultism, the fashions of Art Deco Egyptian revival, and the discourses of interwar archaeological theory. Their ability to symbolize depends on complex entanglements of ancient and modern.

[Insert Figure 4 approximately here] 


\section{<1> Concretizing Labour: Building Megaliths 1901 - 1939}

Perhaps more than any other modern building material, concrete makes the labour necessary to produce it obvious. Concrete must be mixed. Even where a cement mixer is used, human hands must pour, mix, mould and finish. However scientific technologies of cement manufacture become, concrete is based in manual handicraft. It concretizes labour. Historically concrete is linked to a redistribution of skills within the building industries; separating the 'mental' labour of the architect from the bulk of 'manual' labourers (Forty 2012: 232-4). The rapid concreting techniques which spread dramatically in the early twentieth century could be executed with a high ratio of unskilled to skilled labour. "Provided there is proper supervision", concrete's promoters remarked, "concrete ... enables ... work to be carried out at a very low rate" (Lakeman 1918). Concrete enabled the replacement of more highly skilled, expensive, and increasingly unionized builders with less skilled, cheaper, non-unionized labourers (Forty 2012: 226-7). Archaeological concreting was part of this dynamic, yet concreting at heritage sites had additional dimensions: concreting not only allowed preservation and display, it was also an experimental practice giving insights into the past.

However unlikely it may seem, a century ago concrete was a vehicle for utopian medievalism. The 1901 concreting of Stone 56 at Stonehenge continued an ethos of labour promulgated by Ruskin and Morris and late nineteenth century arts and crafts. Detmar Blow had forged a team of hand-picked, experienced, skilled workers and supervisors. As far as possible, this 'community of craftsmen' moved with Blow from site to site, maintaining the continuity of membership Blow felt essential to craft fellowship (Drury 2000). Unusually for an architect of his class, Blow followed Phillip Webb's insistence on the importance of "living there" with his team while they worked (letter, Webb to SPAB, $16^{\text {th }}$ January 1901: SPAB Stonehenge file). The 1901 concrete was unreinforced, and mostly made up of aggregate obtained at or near the site (Blow: Report on Stonehenge (undated): SPAB Stonehenge file). Webb recommended "the concrete should be made of broken flint and chips, with coarse gravel, sand, and the cement not more than 1 to 8 or 9 of hard material..." (letter, Webb to SPAB, 16 ${ }^{\text {th }}$ January 1901: SPAB Stonehenge file). Working this unreinforced cement would have involved techniques close to those of clay, rammed earth or daub construction, technologies that go back centuries in the Wiltshire vernacular. Parallels may even be discovered in the chalk-daub of Neolithic houses occupied when Stonehenge was built. Performed within a continuum of building tradition, the 1901 concreting evoked a politics of labour idealizing the skilled craftsperson and their community. A similar politics reached its fullest expression among advocates of Guild Socialism, who used locally based, de-industrialised building practices to create idealised polities looking back to the middle ages (e.g. Penty, quoted in Swenarton 1989, 187).

Unlike Detmar Blow, later archaeologists commissioned concrete expertise, labour, and equipment from local building firms. These small and medium-sized building firms were well placed to exploit the new economics of concrete, with its redistribution of skilled and unskilled labour. During the First World War, the War Department had contracted W.E. Chivers and Sons of Devizes for concreting, while inter-war house-building and land speculation fuelled the rise 
of Swindon-based Edwin H. Bradley and Sons (Bradley 1983; Haycock 1995). The first archaeologists to commission these firms were the Cunningtons in 1912, who contracted W.E. Chivers \& Sons to re-erect and concrete their two stones at Avebury, using jacks borrowed from the Great Western Railway Company at Swindon (Cunnington 1913). They also contracted Bradley and Sons to supply local aggregate as well as manufacturing pre-cast concrete drainpipes and hiring out the equipment necessary to move 100-ton megaliths (Bradley 1983).

Contracting building firms meant archaeologists were increasingly involved in negotiations with builders, whose expertise was different to that of the archaeologist, and who were not directly employed by them. At the Devil's Den in 1921 concreting was managed by the Office of Works through local intermediaries, including the Wiltshire Archaeological Society and the Cunningtons, who recommended local building firm Rendell of Devizes. Correspondence between the Wiltshire Archaeological Society, who were supervising the work, and the Office of Works reveals anxiety about instructing builders: “"....what ought to be done and how should it be done? Can you give us working orders? I mean precise working directions..." (letter, EH Goddard to C Peers, $1^{\text {st }}$ November 1920: TNA WORK 14/665, his emphasis). The Office of Works provided measured plans, written guidance, and on-the spot instruction for all aspects of the work, not least the recipe for the concrete, which followed standard Office of Works practice 4 parts (locally sourced) aggregate, 2 parts sand and 1 part Portland Cement (Office of Works memo $13^{\text {th }}$ August 1921: TNA WORK 14/665). They also sent "a competent Clerk of Works" from London to explain "what should and should not be done" to the builders (Letter, EH Goddard to C Peers, $3^{\text {rd }}$ December 1920: TNA WORK 14/665, his emphasis).

As commissioners of labour, archaeologists influenced labour relations and wages without controlling them directly. According to the Cunningtons' nephew, who worked with them at Woodhenge and the Sanctuary, Ben Cunnington engaged the labourers, "economiz[ing] labour as much as possible without scamping it", implying he may have preferred firms who kept costs low (Cunnington 1954, 229). At Avebury, Keiller sought to exercise as much control as possible over concreting, effectively contracting builders into the excavation team for the duration. In his earlier excavations at Windmill Hill Keiller gained a reputation for paying good wages. Some local employers, particularly farmers, were "annoyed at losing their farmhands to him" (Rawlins $1999,39)$. During the Avebury years, "Mr Keiller provided welcome employment to many during the years of depression" (ibid). Keiller's desire to exercise full control over concreting probably entailed greater investment in the skills and working practices of his workforce and thus in their pay.

The excavation and concreting of Avebury was a colossal megalithic building project, much bigger than anything attempted previously. Only the Office of Works' inter-war restoration schemes at medieval abbeys and castles are comparable (see Emerick 2013). Up to 250 people were employed at any one time, with interventions spread over distances of half a mile. Equipment streamed in from guardianship sites courtesy of the Office of Works (letter, Keiller to OGS Crawford $27^{\text {th }}$ June 1934: Alexander Keiller Museum). Keiller head-hunted experienced managers from other projects, recruiting W.E.V. Young to oversee the excavation, W. Griffiths to lead megalith re-erection, and a member of building firm, W.E. Chivers and Sons, for 
concreting. Griffiths had been Office of Works foreman at Stonehenge during the 1919-20 reerection and concreting (ibid), while W.E.V. Young and Chivers and Sons had previously worked with the Cunningtons. Concreting was no different to excavation in terms of labour organisation: "I have various gangs on the job," Keiller noted, "each with their particular speciality, e.g. the excavating gang, the re-erecting gang, the concreting gang, the refilling gang, the returfing gang, and so forth" (Letter, Alexander Keiller to Norrington, 18 September 1935: Alexander Keiller Museum). Each gang was led by a hand-picked foreman supplied with a dozen largely untrained men (although Griffiths added his own experienced assistant to his gang). The organizational structure - a small section of men managed by a trusted sergeant - mirrored that used for small military formations such as machine gun sections during the First World War ${ }^{3}$. The ratio of skilled to unskilled labour mirrored military concreting, which had given many men their first experience of concreting.

Keiller's innovations in organization and management reflect the 'Scientific Management' trends of earlier twentieth century Fordism. From its beginnings in the 1880s scientific management was closely allied to the marketing of 'Concrete Systems' that promised to do away with costly, old-fashioned practices in favour of modern, cost-efficient methods (Forty 2012: 236-40). Time and motion studies of labourers using concrete showed how traditional building might be modernized. By 1912, studies of labourers by Frederick Taylor recorded that it took 0.21 fractions of a minute to lift a bag of cement, 0.83 to carry it $100 \mathrm{ft}$ and 0.09 to dump it into a hopper (Taylor and Thompson 1912, cited in Forty 2012: 237). Using such observations Taylorist managers could calculate the labour costs associated with each task and predict future costs. At Avebury, Keiller observed the work of his concreting and re-erecting gangs, not to predict the future but to interpret the past. The first stone of the West Kennet Avenue, he noted, was re-erected in 4 days, before any industrial equipment had arrived: “...if one replaced hide ropes for steel ones (upon which we put no undue stress) and shorter hide ropes for the iron staples (which we used on two occasions but which were not essential), we employed no equipment which would not have been at the disposal of the original builders of the Avenue" (letter, Keiller to Crawford $27^{\text {th }}$ June 1934: Alexander Keiller Museum). Using his 12 initially untrained men as a guide, Keiller estimated 250 of their prehistoric predecessors, "all trained and experienced", could have erected 20 stones in those same 4 days, and the entire West Kennet Avenue in 40 days. Subsequently, Keiller sought to re-erect stones "under the original conditions" as much as possible (Chitty 1992, 62), so that the time taken to do so could be recorded, and the observations used to investigate prehistory.

The experimental benefits of concreting large sarsens were such that Keiller undertook entirely novel non-archaeological building projects. In 1936-7, in the midst of their work at Avebury, the re-erecting and concreting gangs were placed at the disposal of a committee of writers and arts patrons building a memorial to Edward Thomas (Thornton 2011). The memorial comprised a

3 The number 13 was consistently applied to all the work gangs, who proceeded in an anti-clockwise fashion around the henge circuit; perhaps coincidentally, the number 13 had been identified by Keiller (following Margaret Murray) as the number of witches within sixteenth century Scottish covens (see Keiller 1921). 
single erect sarsen, set in a hidden concrete bed, with a plaque designed by Patrick Abercombie. "Since moving large megaliths ... comes under our work annually," Keiller observed, "we have had not inconsiderable experience therein". The skills possessed by his labourers were "perhaps second only to that enjoyed by the original builders of [Avebury] at the close of the Neolithic Age, and ... the methods that we employ are substantially the same as those utilised some 3800 years ago". Building Thomas' modern memorial could be justified as archaeological research, since it would allow Keiller to "obtain data concerning such matters as how many men it would take to transport a stone of a given weight over various types of ground and so on" (Keiller 1937 quoted in Thornton 2011). Calculating the "man-hours" devoted to building megaliths underlined the "achievements" of prehistory, demonstrating progress and advancement through the distinctly modern (and authoritarian) values attributed to commanding labour.

Concreting megaliths had consequences for how the prehistoric was understood in the modern era. Most concreting programmes assumed megaliths were conceived and constructed as single-phase buildings with logical design plans. At Avebury concrete markers were extrapolated to locations where, despite an absence of archaeological evidence, it was felt stones must once have stood (Edwards 2000: 68-9). At Woodhenge and the Sanctuary it was assumed concentric settings of timber posts and of standing stones must have stood together at the same time. The plans preserved and displayed in concrete were important, not only as archaeological drawings, but as concepts once existing in the minds of prehistoric architects. Woodhenge and the Sanctuary were invisible to most visitors before they were concreted, but now tourists, including archaeologists, could visit them. They were permanent fossils, or typesites that could be used to interpret other sites. Woodhenge and Stonehenge enabled Kendrick and Hawkes (1932) to identify "the henge" as a distinct monument type that could be extrapolated across large parts of the British Isles. Concreting was not only a form of preservation and display, it also concretized the idea of prehistory.

If concrete megaliths had consequences for prehistory they also contributed to developments in modernism. A number of studies highlight the significance of Wiltshire megaliths in British Neo-Romanticism and Surrealism during the Concrete Age (Edmonds and Evans 1991, Evans 2004, Smiles 2002, 2004, Hauser 2007). Paul Nash first visited Avebury in 1933, just before Keiller's concreting began but years after the Cunningtons re-erected two megaliths and created an installation of concentric concrete light blue rectangles and dark red cylinders at the Sanctuary. Nash disparaged Keiller's concreting for destroying the "primal magic" of the site (Nash 1951, cited in Smiles 2004: 91), but one wonders whether he knew one of the two standing stones he wrote of in 1934 had been concreted upright by the Cunningtons? One of these became Nash's "Stone Personage" and was worked into his paintings "Druid Landscape" and "Landscape of the Megaliths" (Walker 2007:17-9). A letter from Keiller to Nash indicates Keiller was himself enlisted to photograph Nash's 'personages' (letter, Keiller to Nash $8^{\text {th }}$ July 1938: Tate TGA 7050/704). Nash's (1935) "Equivalents for the Megaliths" shows the view from the Sanctuary and includes a blue rectangle and red cylinder recalling the Cunningtons' concrete markers. Shortly after Nash produced his abstract painting that might, in fact, represent concrete megalith equivalents, Eileen Agar photographed concreting at Avebury 
(Figure 5). Her megalith, ensnared in chains and ropes, recalls her "Angel of Anarchy" exhibited in the International Surrealist Exhibition of 1936, as well as the irreverent photographs she made of Ploumanac'h rocks (Agar 1988; Walker 2007: chapter 3). Just as modernists were drawn to the concretized megalithic at Stonehenge (see above), so they engaged with the surreal juxtapositions of primitive and modern represented by concreting megaliths.

[Insert Figure 5 approximately here]

\section{$<1>$ Conclusion}

"The most beautiful music in the world" to Alexander Keiller was "the sound of the cement mixer pounding the cement" for a fully restored Avebury. Keiller's dream was that concrete would carry his vision of prehistory into the future ensuring resurrected megaliths would stand "3000 years after I am gone" (Chitty 1992, 62). Early twentieth century archaeologists believed concrete was indestructible. It would preserve their megaliths in perpetuity. Such unfaltering optimism has gone. The elixir of eternal youth has worn off Stonehenge and Avebury concrete. Water seeps slowly in, setting off alkali-silica reactions that cause carbonation and steel corrosion internally (Tarrant 2010). Minerals leech out through cracks in the surface (English Heritage 2013). The revelation of concrete's physical decline coincides with fundamental transformations in attitudes to concrete. Concrete no longer inspires many to dream of utopian futures. Since the early 1970s, concrete has more often evoked "jungles" thought to threaten the supposedly fragile heritage values of locality and distinctiveness. Concrete's ubiquity has also led to its banality. As Mike Pitts commented of the Sanctuary: "you can see concrete bollards in your supermarket car park" (2000:239). If it is not dystopian, concrete is, at the least, disenchanted.

Much of the megalithic concreting we have discussed would be unthinkable today. A slew of international charters (e.g. the Venice, Lausanne, Riga and Nara charters), planning guidance (PPG 15), British Standards (BS7913) and English Heritage policy statements (English Heritage 2001,2008 ) suggest reconstructing megaliths in situ would be much harder to achieve.

Furthermore, contemporary attitudes to concrete mean highly visible concrete installations like those at Woodhenge, The Sanctuary and Avebury are a thing of the past. While English Heritage policy states restoration should be "clearly distinguishable from original fabric" (2001:para 47), British Standard 7913 says new work should be "carefully matched and blended" with existing fabric (1998). Although our research suggests historic concrete is less out of keeping with its location than many would assume - indeed, it sometimes physically incorporates archaeologically significant materials from the site - the current aversion to concrete means it is generally avoided or hidden where possible. The rediscovery of the Beckhampton Avenue at Avebury in 1999 throws the differences between the earlier and later twentieth century into relief. It was eventually decided neither to re-erect excavated megaliths, nor to indicate the locations of reburied stones or stone-holes on the ground (Gillings and Pollard 2004:3), although there is an interpretation panel at the Cunnington's re-erected Longstones, with a plan of the excavated features. In the later twentieth century dislike of concrete was such that 
heritage concrete became particularly vulnerable to removal and replacement with other materials (including timber, and most recently, at the Stonehenge Aubrey Holes, metal alloy). There have been several attempts to remove the Cunnington's installation at Woodhenge, the latest advanced in 1996 (English Heritage: Woodhenge Archive), and the Sanctuary has lost the Cunnington's concrete plinth with its brass plaque.

If modernism has become our antiquity "its ruins have become every bit as fascinating, poignant and morbid as those of the Greeks and Romans were in the eighteenth century" (Hatherley 2008:45). Today, the ruins of modernism largely comprise concrete. But, even more interestingly, the ruins of other ages are often partly of concrete too. These are the ruins of the modern past. In this paper we explored the building of modern prehistories using concrete. Concrete's telluric simplicity suited this modern-ancient technology to prehistoric sites, while the use of local materials (including fragments of sarsen megalith) as aggregate means the concrete includes materials likely to be treated as prehistoric under excavation conditions. After the First World War, concrete acted as a sign of modernity, but also allowed visitors to imaginatively grasp aspects of prehistory - such as the size, shape and arrangements of vanished megaliths and timber posts. The labour of concreting was intimately linked to the development of modern theories of prehistoric societies. Experimental concreting allowed archaeologists to gauge the significance of the prehistoric achievement in terms of the labour devoted to megalith construction. Once megaliths had been concreted, they presented archaeologists with concrete examples - type sites - which allowed formal comparison between sites. However much some may wish to present megaliths as prehistoric, there is no denying they are the ruins of a distinctively modern prehistory - a prehistoric imagination cast in concrete.

\section{$<1>$ Acknowledgements}

We would like to thank museum curators and archivists for access to the records and photographs of the episodes discussed in this paper: Ros Cleal and staff at the Alexander Keiller Museum, Avebury; David Dawson and staff at the Wiltshire Museum, Devizes; Matthew Slocombe and staff at the Society for the Protection of Ancient Buildings; staff of the English Heritage Archive, Swindon; staff at the National Archives, Kew; and Adrian Glew and staff at the Tate Britain archive. Mike Pitts kindly allowed us to choose from his photographs of Woodhenge and the Sanctuary. An early version of this paper was presented in Kenny Brophy \& Vicki Cummings' session 'Psychoarchaeology: Theory, Method, Practice' at TAG in December 2011. It has taken a while to set.

\section{$<1>$ Bibliography}

Agar, E. 1988. A Look at my Life. London: Methuen.

Anon. 1883. [Report of the Stonehenge Committee]. Proceedings of the Society of Antiquaries of London_vol 9, 9-16. 
Barber, M. 2014a. 'Restoring' Stonehenge 1881-1939. English Heritage Research Report Series 6/2014. Portsmouth: English Heritage.

Barber, M. 2014b. Stonehenge Aerodrome and the Stonehenge Landscape. English Heritage Report Series 7/2014. Portsmouth: English Heritage.

Bergdoll, B. and Christensen, P., eds. 2008. Home Delivery: Fabricating the Modern Dwelling. New York: Museum of Modern Art.

Bradley, L. 1983. Bradley: Building on a Name: the history of Edwin H Bradley \& Sons Limited. Privately published.

Chitty, S. 1992. Antonia White: Diaries 1926-1957.

Cleal, R.M.J., Walker, K.E., and Montague, R. 1995. Stonehenge in its Landscape: twentiethcentury excavations. London: English Heritage.

Cohen, J.L. and Moeller, G.M. eds., 2006. Liquid Stone: New Architecture In Concrete. New York: Princeton Architectural Press.

Collins, P. 1959. Concrete: the vision of a new architecture. London: Faber and Faber.

Croft, C. 2004. Concrete Architecture. Layton: Gibbs Smith.

Cunnington, M.E. 1913. "The re-erection of two fallen stones, and the discovery of an interment with drinking cup, at Avebury". Wiltshire Archaeological and Natural History Magazine vol XXXVIII, no CXIX, June 1913, 1-11.

Cunnington, M.E. 1929. Woodhenge. A Description of the Site as revealed by Excavations carried out there by Mr and Mrs B.H. Cunnington, 1926-7-8. Also of Four Circles and an Earthwork Enclosure. Devizes: George Simpson \& Co, Devizes, Ltd.

Cunnington, M.E. 1931. "The 'Sanctuary' on Overton Hill, near Avebury". Wiltshire Archaeological and Natural History Magazine vol XLV no CLIV, June 1931, 300-335.

Cunnington, R.H. 1954. "The Cunningtons of Wiltshire". Wiltshire Archaeological and Natural History Magazine vol LV, no CC, June 1954, 211-236.

Curran, B.A., Grafton, A., Long, P.O., Weiss, B. 2009. Obelisk: A History. Cambridge, Mass: MIT Press.

Drury, M. 2000. Wandering Architects : in pursuit of an Arts and Crafts ideal. Stamford: Shaun Tyas. 
Edmonds, M., Evans, C. 1991. Excavating the Past: The Place of the Present: Art and Archaeology in Britain. London: Kettle's Yard Gallery.

Edwards, B. 2000. "Avebury and other not-so-ancient places: the making of the English heritage landscape". In H. Kean, P. Martin, S. Morgan, eds. Seeing History: Public History in Britain_Now, 65-79. London: Francis Boutle.

Emerick, K. 2014. Conserving and Managing Ancient Monuments: Heritage, Democracy, and Inclusion. Woodbridge: Boydell \& Brewer.

English Heritage. 2001. English Heritage Policy Statement on Restoration, Reconstruction, and Speculative Recreation of Archaeological Sites including Ruins. https://www.englishheritage.org.uk/publications/re-arch/re-arch2001.pdf, accessed $2^{\text {nd }}$ February 2015.

English Heritage. 2008. Durability Guaranteed. Pulhamite rockwork - Its conservation and repair. Swindon: English Heritage.

English Heritage. 2013. Concrete. Practical Building Conservation Series. English Heritage/Ashgate.

Evans, C. 2004. "Unearthing Displacement: surrealism and the 'archaeology' of Paul Nash". In C. Renfrew, C. Gosden, E. DeMarrais, eds. Substance, Memory, Display: Archaeology \& Art, 107118. Cambridge: MacDonald Institute for Archaeological Research.

Forty, A. 2006. "A Material Without a History", in Cohen, J.L. and Moeller, G.M. eds., 2006. Liquid Stone: New Architecture In Concrete. New York: Princeton Architectural Press, 34-45.

Forty, A. 2012. Concrete and Culture: A Material History. London: Reaktion Books.

Gillings, M. and Pollard, J. 2004. Avebury. London: Duckworth.

Hatherley, O. 2008. Militant Modernism. Ropley, Hants: O Books.

Haycock, L. 1995. A History of WE Chivers \& Sons of Devizes: A Century of Building 1884-1985. Pipers Publications: Bath.

Hauser, K. 2007. Shadow Sites: Photography, archaeology and the British landscape 1927-1955. Oxford: Oxford University Press

Hill, R. 2008. Stonehenge. London: Profile.

Keiller, A. 1922. The Personnel of the Aberdeenshire Witchcraft Covens in the Years 1596-7. London: Privately Published. 
Keiller, A. and Piggott, S. 1936. "The recent excavations at Avebury". Antiquity 10, 417-427.

Kendrick, TD and Hawkes, CFC. 1932. Archaeology in England and Wales 1914-1931. London: Methuen \& Co. Ltd.

Krier, L., 1985. Albert Speer : Architecture, 1932-1942. Archives d'architecture moderne. University of California.

Lakeman, A., 1918. Concrete Cottages, Small Garages and Farm Buildings. London.

Latour, B. 1993. We Have Never Been Modern. Harvard : Harvard University Press.

Le Corbusier, 1927. Towards a New Architecture. London : Butterworth Architecture.

Lukis, W.C. 1881. "Stonehenge". The Antiquary vol IV, 225-6.

Martin, J.L., Nicholson, B., Gabo, N. 1937. Circle: International Survey of Constructive Art. London.

Massingham, H.C. 1926. Downland Man. London: Jonathan Cape Ltd.

Moeller, G.M. 2006. "Sculptural Form. Reinforced Concrete and the Morality of Form"; in Cohen \& Moeller, 156-215.

Murray, L. 1999. Alexander Keiller: A Zest for Life. Swindon: Morven Books.

Noyes, E. 1913. Salisbury Plain. Its Stones, Cathedral, City, Valley and Folk. London: Dent.

Passmore, A.D. 1922. "The Devil's Den dolmen, Clatford Bottom. An account of the monument and of work undertaken in 1921 to strengthen the north-east upright". Wiltshire Archaeological and Natural History Magazine 41, 532-30.

Peers, C. 1931. "The treatment of old buildings". Architectural Journal $3^{\text {rd }}$ series vol 38, 311-320.

Peirce, C. 1998. The Essential Peirce vol 2: Selected Philosophical Writings 1893-1913. Indiana: Indiana University Press.

Petrie, F. 1880. Stonehenge : Plans, Description and Theories. (Reprinted 1989). London: History \& Mysteries of Man.

Piggott, S. 1950. William Stukeley; an eighteenth-century antiquary. Oxford: Clarendon Press.

Piggott, S. 1962. The West Kennet Long Barrow, Excavations 1955-6. London: HMSO. 
Pitt Rivers, A.H.L.F. 1893. Stonehenge. Report on the Condition of Stonehenge by the Inspector of Ancient Monuments. $2^{\text {nd }}$ October 1893. TNA WORK 14/213.

Pitts, M. 2000. Hengeworld. London: Century

Pitts, M. 2008. "A Photo by Bill Brandt, and the Intimacy of Perceptions of Stonehenge and Landscape". Landscapes 1, 1-27.

Portland Cement Association. 1913. Everyday Uses of Concrete.

Rawlins, M. 1999. Butcher, Baker, Saddlemaker: Village Life in Avebury from 1920-1974. Privately published.

Renfrew, C. 1973. Before Civilization: The Radiocarbon Revolution and Prehistoric Europe. Pimlico: London.

Ruskin, J. 1871 [1849]. The Seven Lamps of Architecture. New York: John Wiley \& Son.

Secord, J.A. 2004. "Monsters at the Crystal Palace"; in S de Chadarevian, N Hopwood (eds) Models. The third dimension of science, 138-169. Stanford: Stanford University Press.

Smiles, S. 2002. "Equivalents for the Megaliths: Prehistory and English Culture, 1920-1950", in Corbett, D.P. and Y. Holt, eds. The Geographies of English Art 1880 - 1940. Yale University Press: New Haven and London.

Smiles, S. 2004. Antiquity and Modern Art in Britain, c. 1930-1950; Archaeological Review from Cambridge 19 (1), 81-98.

Stanley, C.C. (1979) Highlights in the History of Concrete. Cement and Concrete Association: Slough

Stout, A. 2008. Creating Prehistory: Druids, Ley Hunters and Archaeologists in Pre-war Britain. Oxford: Blackwell.

Swenarton, M. 1989. Artisans and Architects: The Ruskinian Tradition in Architectural Thought. Basingstoke: MacMillan Press.

Tarrant, A.S. 2010. Analysis of Concrete Markers at Avebury World Heritage Site. Unpublished MA Thesis, University of London.

Thornton, C.G. 2011. "The Edward Thomas Memorial Stone, Shoulder of Mutton Hill, Steep". The Edward Thomas Fellowship Newsletter 66, 24-32 . 
Thurley, S. 2013. Men from the Ministry: how Britain saved its heritage. London: Yale University Press.

Tuhy, J.E. 1983 Sam Hill: The Prince of Castle Nowhere. Timber Press.

Walker, I. 2007. So Exotic, So Homemade: Surrealism, Englishness and Documentary Photography. Manchester: Manchester University Press.

Weary, J. 2009. Edison's Concrete Piano: flying tanks, six-nippled sheep, walk-on-water shoes and 12 other flops from great inventors. Toronto: ECW Press.

Woodward, C. 2001. In Ruins. London: Chatto \& Windus.

Yablon, N. 2010. Untimely Ruins: The Archaeology of American Urban Modernity 1819-1919. London: University of Chicago Press. 